\title{
Relationship of body fat stores and leptin expression in adipose tissue in African cows of different genotype*
}

\author{
A. Jenet ${ }^{1,2}$, S. Fernandez-Rivera ${ }^{1}$, M. Kreuzer ${ }^{2}$, W. Langhans ${ }^{3}$, \\ D. Werling ${ }^{3}$, M. Saurer ${ }^{4}$ and M. Senn ${ }^{3,5}$ \\ ${ }^{I}$ International Livestock Research Institute (ILRI) \\ P.O. Box 5689, Addis Ababa, Ethiopia \\ Institute of Animal Science, Federal Institute of Technology (ETH) ETH-Centre/LFW, \\ ${ }^{2}$ Animal Nutrition, ${ }^{3}$ Physiology and Animal Husbandry \\ CH-8092 Zurich, Switzerland \\ ${ }^{4}$ Paul Scherrer Institut (PSI), CH-5232 Villigen, Switzerland
}

\begin{abstract}
Indigenous cows adapted to harsh environments are producing only limited amounts of milk and do not respond to additional feed supply with increases in milk production. Leptin, a regulator of body fat stores, may be differently expressed in indigenous Boran compared to crossbred cows, and hence be responsible for different nutrient partitioning. Body condition score (BCS) and body fat was estimated in 20 Boran and 21 crossbred cows and leptin expression was quantified in fat cells. Results revealed a significant relationship of leptin expression and BCS as well as body fat. However, relationships of the measured variables were only slightly $(\mathrm{P}<0.15)$ differently expressed between genotypes. However, leptin may be involved in the expression of different responses in milk production to additional feed between Boran and crossbred dairy cows.
\end{abstract}

KEY WORDS: leptin, body condition score, Bos indicus, deuterium, dairy, adipose tissue

\section{INTRODUCTION}

In contrast to Bos taurus breeds and crossbred cows, Bos indicus cows respond only to a very limited extent with higher milk production to increases of feed provided (Jenet et al., 2004). Zebu cattle are adapted to harsh environments in tropical countries and to extended phases of seasonal undernutrition. Leptin may play a putative role in regulating the energy deposits of adapted cattle. Leptin is

\footnotetext{
* Supported by the Swiss Centre for International Agriculture (ZIL/SDC)

${ }^{5}$ Corresponding author: e-mail: markus.senn@inw.agrl.ethz.ch
} 
considered to signal adiposity and/or to reflect dynamic changes in metabolite flow in and out of the adipocyte. This paper investigates the relationship between body condition score, fat and leptin expression of a local Bos indicus and an higher yielding crossbred cow.

\section{MATERIAL AND METHODS}

Twenty Boran cows (Bos indicus) and 21 crossbreds (Holstein $\times$ Boran) had been selected at time of entering the third lactation. Animals where subjected to 1.0 or $1.4 \times$ maintenance energy requirements (AFRC, 1993). This, and contrasting feeding levels in previous lactations (Jenet et al., 2004) should facilitate a relatively high variation among animals. Diets always consisted of proportionately $65 \%$ grass hay (mainly Cynodon dactylon) and 35\% wheat bran of total dietary dry matter (DM), and feed was provided once daily after the morning milking (cf. Jenet et al., 2004). Feed offered and refused was recorded daily throughout lactation 3 . Body weight (BW) and body condition scores (BCS) were recorded every second week, the latter applying a scale ranging from meagre $(=1)$ to obese $(=9)$ (Nicholson and Butterworth, 1986).

Adipose tissue (AT) samples $\left(50-70 \mathrm{mg}\right.$ ) were taken in the $9^{\text {th }}$ week of lactation at $07.00 \mathrm{~h}$ before feeding by biopsy from subcutaneous fat depots in $8 \mathrm{~cm}$ distance from the tail head. The samples were stored in $400 \mu 1$ RNAlater (Ambion, Austin, TX, USA). Total RNA was extracted using RNeasy Mini spin columns (Qiagen, Hilden, Germany). The cDNA was synthesized with the AMV reverse transcriptase system (Promega, Madison, WI, USA) using $30 \mu \mathrm{g}$ total RNA and following the manufacturer's recommendations. Real time PCR was employed to quantify the expression of adipose tissue total RNA transcripts of bovine leptin and GAPDH as a referencing housekeeping gene. Quantitative PCR was performed on an ABI Prism 7700 Sequence Detection System using Taq-Man PCR reagents (Applied Biosystems, Foster City, California, USA). The RNA quantification of the target and treatment differences was accomplished by comparing the amount of target with the standard GAPDH gene expression.

Animals were fasted on day 79 of lactation for $12 \mathrm{~h}$ before deuterium oxide application and fasting continued for another $9 \mathrm{~h}$. Animals were weighed $( \pm 1 \mathrm{~kg})$ and a background blood sample was collected from the jugular vein, followed by an injection of 99.8 atom \% deuterium oxide (Armar AG, Döttingen, Switzerland) equivalent to $0.3 \mathrm{~g} / \mathrm{kg}$ fasted BW into the jugular vein. Blood samples were taken 5 , 7 , and $9 \mathrm{~h}$ post infusion. Concentrations in plasma were analysed using an isotope mass spectroscopy (Delta-S, Finnigan, Bremen, Germany). Deuterium space (kg) was calculated according to Speakman (1998). The gastrointestinal tract (GIT) of the cows was assumed to amount to 0.20 of BW, and empty BW (EBW) was described as BW-GIT (NRC, 2001). Empty body fat (EBF; kg) was estimated according to Brown et al. (1989) as $0.3790 \times \mathrm{BW}(\mathrm{kg})-0.2955 \times \mathrm{D}_{2} \mathrm{O}$-space $(\mathrm{kg})-42.163$. 
To determine the relationship between variables, regression analysis was carried out by the general linear model of SAS (2001) using the 'solution' statement and the sum of square type 4. Genotype was set as class variable and factors were BCS, genotype and their interaction. Non-significant terms (starting with $\gamma_{\mathrm{k}}$, and followed by $\alpha \beta_{\mathrm{ij}}$ ) were excluded in subsequent analyses.

$$
\begin{aligned}
& Y_{i j k}=\mu+\alpha_{i}+\beta_{j}+\gamma_{k}+\alpha \beta_{i j}+e_{i j k l} \\
& Y_{i j k}=\mu+\alpha_{i}+\beta_{j}+e_{i j l} \\
& Y_{i j k}=\mu+\alpha_{i}+e_{i l}
\end{aligned}
$$

$\mathrm{Y}_{\mathrm{ijk}}=$ dependent variable, $\mu=$ intercept, $\alpha_{\mathrm{i}}=$ effect of BCS, $\beta_{\mathrm{j}}=$ effect of genotype, $\gamma_{\mathrm{k}}=$ feeding level in the third lactation, and $\mathrm{e}_{\mathrm{ijk}}=$ residual error.

\section{RESULTS AND DISCUSSION}

The comparison of the estimated fat content and BCS estimate validated the scoring system developed by ILCA (Nicholson and Butterworth, 1986) for tropical cows (Figure 1, left). An increase in one unit of BCS was associated with an increase of $3.23( \pm 0.305) \%$ of fat content or, reversely expressed, an increase in $1 \%$ of fat content was associated with an increase of $0.23( \pm 0.022)$ units of BCS. Nicholson and Butterworth (1989) reported that one BCS unit was equivalent to $24 \mathrm{~kg} \mathrm{BW}$, which slightly exceeded the present range.
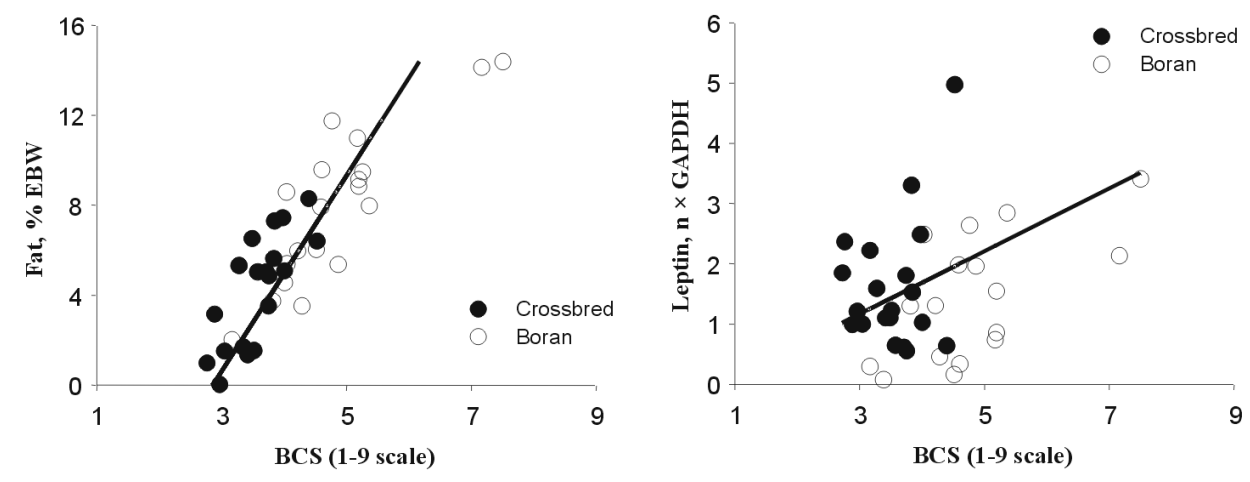

Figure 1. Relationship between $B C S$ and fat content of EBW $\left(\mathrm{R}^{2}=0.74 ; \mathrm{P}<0.001\right)$ and the expression of leptin in adipose tissue of Boran and crossbred cows $\left(\mathrm{R}^{2}=0.10 ; \mathrm{P}<0.05\right)$. Differences between genotypes were not significant $(\mathrm{P}<0.15)$

Leptin is considered to signal the central nervous system about the size of the fat stores and/or to reflect dynamic changes in metabolite flow in and out of the adipocytes. Leptin expression in adipose tissue was weakly correlated with BCS (Figure 1, right), and EBF $\left(\mathrm{R}^{2}=0.09 ; \mathrm{P}<0.10\right)$, but did not significantly differ 
between genotypes. Each unit increase in BCS resulted in an increase of 0.52 $( \pm 0.261)$ arbitrary units for leptin. It seemed that crossbred cows responded more rapidly in leptin to corresponding changes in BCS; however, the variation in BCS in crossbred cows was not sufficiently large to allow conclusions. Chilliard et al. (2001) reported that leptin is decreased in undernutrition. The decrease in leptin in turn increases cortisol, which contributes to metabolic adaptations to undernutrition (e.g., enhanced protein mobilization and gluconeogenesis, stimulated feed intake, inhibited reproduction). It is therefore tempting to speculate that the weak leptin response in Boran cows allows for maximum storage of energy during the vegetative season, hence, providing an evolutionary advantage for survival during harsh conditions.

\section{CONCLUSIONS}

Leptin expression was related to changes in body fat stores. However, relationships between genotypes of the measured variables were only slightly $(\mathrm{P}<0.15)$ different. Thus, leptin may be one factor responsible for the different nutrient partitioning and effects on milk production of Boran and crossbred genotypes under conditions where cows are offered additional feed. However, further investigations are needed with larger variation in BCS in the crossbreds.

\section{REFERENCES}

AFRC (Agricultural and Food Research Council), 1993. Energy and Protein Requirements of Ruminants. CAB International, Wallingford (UK)

Brown D.L., Taylor S.J., Depeters E.J., Baldwin R.L., 1989. Influence of sometribove, USAN (recombinant methionyl bovine somatotropin) on the body composition of lactating cattle. J. Nutr. 119, 633-638

Chilliard Y., Bonnet M., Delavaud C., Faulconnier Y., Leroux C., Djiane J., Bocquier F., 2001. Leptin in ruminants. Gene expression in adipose tissue and mammary gland, and regulation of plasma concentration. Domest. Anim. Endocrinol. 21, 271-295Jenet A., Yimegnuhal A., FernandezRivera S., Tegegne A., Osuji P.O., McCrabb G.J., Kreuzer M., 2004. Long-term response to feeding level in lactational performance of Boran (Bos indicus) and Boran $\times$ Holstein cows. Anim. Sci. 78, 331-343

NRC, 2001. Nutrient Requirements of Dairy Cattle. 7th revised Edition. National Academic Press, Washington, DC

Nicholson M.J., Butterworth M.H., 1986. A Guide to Condition Scoring of Zebu Cattle. International Livestock Centre for Africa, Addis Ababa (Ethiopia)

SAS, 2001. SAS/STAT User's Guide: Statistics, Version 8.12, SAS Institute INC., Cary, NC

Speakman J.R., 1998. Doubly Labelled Water: Theory and Practise. Chapman Hall Ltd., London, pp. 399 